\title{
Erratum to: A viability theory for digital businesses: Exploring the evolutionary changes of revenue mechanisms to support managerial decisions
}

\author{
Michaela Sprenger $^{1} \cdot$ Tobias Mettler $^{1} \cdot$ Robert Winter $^{1}$
}

Published online: 6 April 2016

(C) Springer Science+Business Media New York 2016

Erratum to: Inf Syst Front (2016)

DOI 10.1007/s10796-016-9638-x

Due to a typesetting error, some crosses $(\mathrm{x})$ in Table 1 were shifted to the wrong columns. The original version has been corrected.

The online version of the original article can be found at doi:10.1007/ s10796-016-9638-x.

Tobias Mettler

tobias.mettler@unisg.ch

Michaela Sprenger

michaela.sprenger@unisg.ch

Robert Winter

robert.winter@unisg.ch

Institute of Information Management, University of St. Gallen,

Unterer Graben 21, 9000 St. Gallen, Switzerland 